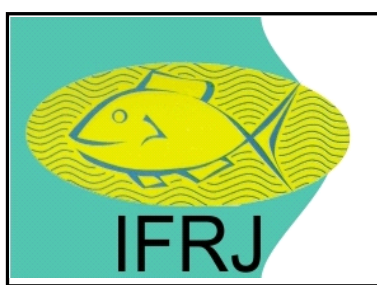

Available online at: http://ejournal-balitbang.kkp.go.id/index.php/ifrj

e-mail:ifrj.puslitbangkan@gmail.com

INDONESIAN FISHERIES RESEARCHJOURNAL

Volume 23 Nomor 2 December 2017

e-ISSN: 2502-6569

Accreditation Number: 704/AU3/P2MI-LIPI/10/2015

\title{
COMPOSITION AND DISTRIBUTION OF DOLPHIN IN SAVU SEA NATIONAL MARINE PARK, EAST NUSA TENGGARA
}

\author{
Mujiyanto*1, Riswanto ${ }^{1}$, Dharmadi ${ }^{2}$ and Wildan Ghiffary ${ }^{3}$ \\ ${ }^{1}$ Research Institute for Fisheries Enhancement and Conservation, Cilalawi Street No. 1, Jatiluhur Purwakarta, \\ West Java Indonesia - 41152 \\ ${ }^{2}$ Center for Fisheries Research and Development, Ancol - Jakarta, Indonesia \\ ${ }^{3}$ Fusion for Nature - Master Candidate of Wageningen University, Drovendaalsesteeg 4, 6708 PB Wageningen, Belanda \\ Received; Februari 20-2017 Received in revised from December 22-2017; Accepted December 28-2017
}

\begin{abstract}
Dolphins are one of the most interesting cetacean types included in family Delphinidae or known as the oceanic dolphins from genus Stenella sp. and Tursiops sp. Migration and abundance of dolphins are affected by the presence of food and oceanographic conditions. The purpose of this research is to determine the composition and distribution of dolphins in relation to the water quality parameters. Benefits of this research are expected to provide information on the relationship between distributions of the family Delphinidae cetacean (oceanic dolphins) and oceanographic conditions. The method for this research is descriptive exploratory, with models onboard tracking survey. Field observations were done in November 2015 and period of March-April 2016 outside and inside Savu Sea National Marine Park waters. The sighting of dolphin in November and MarchApril found as much seven species: bottlenose dolphin, fraser's dolphin, pantropical spotted dolphin, risso's dolphin, rough-toothed dolphin, spinner dolphin and stripped dolphin. The highest species distribution noted in the Savu Sea is spinner dolphin, pantropical spotted dolphin, roughtoothed dolphin and frazer's dolphin. The existence of dolphins in Savu Sea is more related with sea surface temperature than others oceanographic parameters. This condition is suspected due to the influence of sea surface temperature to body temperature of dolphin especially for foraging activities. The habit of dolphin is more active around Sumba Island and Daratan Timor waters while in the evening the animal is usually going to Manggarai and Rote Ndao Islands waters to rest.
\end{abstract}

Keywords: Composition; distribution; dolphin; oceanography; savu sea

\section{INTRODUCTION}

Indonesian waters are enriched with the diversity of cetacean. There are approximately 31 species (whale, dolphin, and porpoise) from the total of 86 species of cetacean in the world. Several species of cetacean are categorized as rare and endangered (Klinowska, 1991; Barnes, 1996; Rudolph et al., 1997; Kahn, 2003; Setiawan, 2004; Fauziah et al., 2006). Cetacean migration pattern is from Pacific Ocean to Indian Ocean and vice versa through Sunda Kecil Islands with the distance of $900 \mathrm{~km}$ from Sunda Strait to Sahul shelf (Klinowska, 1991). Savu Sea National Marine Park is known as the migration route for 31 species marine mammals which consist of 18 species of whale, 12 species of dolphin, and 1 species of dugong (PetSoedo, 2002; Mustika, 2006).
Dolphins usually have high mobility and live in a group. A group of dolphin moves to chase their preys such as small pelagic fish. This phenomenon is often used by the fishermen to detect the location of schooling of fish (Priyono, 2013). These marine mammals tend to live in shallow waters. This makes them vulnerable to harmful environmental condition affected by some factors such as toxic waste and lack of food availability, resources exploitation both direct and indirect like shipping traffic and watch dolphin commercial program. Those all factors might contribute to dolphin existence and fishery problems (Reeves et al., 2003; Wellset et al., 2004).

The availability of food and oceanography condition such as temperature, salinity, current and tide are affecting the abundance and the migration of dolphin. 
This study describes the composition and distribution of dolphin based on sea surface temperature, $\mathrm{pH}$, salinity, dissolved oxygen and total dissolved solid.

\section{MATERIALS AND METHODS}

Field research was conducted at the Savu Sea National Marine Park, East Nusa Tenggara period in November 2015 and March-April 2016. The observation areas covered the waters of Kupang District, Rote Ndao District, South Center Timor District, Sabu Raijua District, East Sumba District, Central Sumba District, West Sumba District, and Southwest Sumba District. (Fig. 1).

Direct observation of cetacean was conducted by using line transect zigzag and single observer/platform method (Fig. 1). The ship moved to the observation area with speed of 7-8 knots in average. The observation was started from 6 a.m. to 6 p.m., teams were rotated every two hours (Kahn, 2014). Ships directed to the point of invisibility cetacean and after

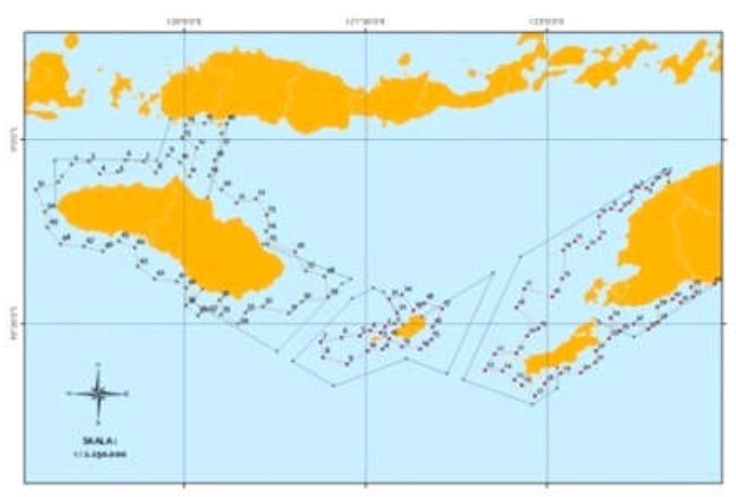

(a)

Track observation of cetacean and monitoring of oceanography parameters nearing the place, the ship's speed was reduced and stopped at a distance of 300 meters from the cetacean. Regular scanning of the surrounding seas with marine binoculars (Canon EOS 60D; Zoom lens Canon EF 70-300 mm) further increased the visual survey range and were frequently used to investigate initial sighting cues.

Data recorded for each sighting included: date and time, GPS location and area description (Kahn, 2014), species is identified with the guide to Marine Mammals of The Word by Reeves et al. (2003) and literature from Jefferson et al. (1993); Jefferson \& Curry (1994). Estimated group size and composition (individual counts at surface), any cetacean species associations (mixed species groups), distance from vessel, direction of travel when first sighted and behavioural categories were done Carwadine. (1995). Photography and video data after whenever possible and sighting conditions were also done. Comprehensive data of some oceanographical parameters are shown in Table 1.

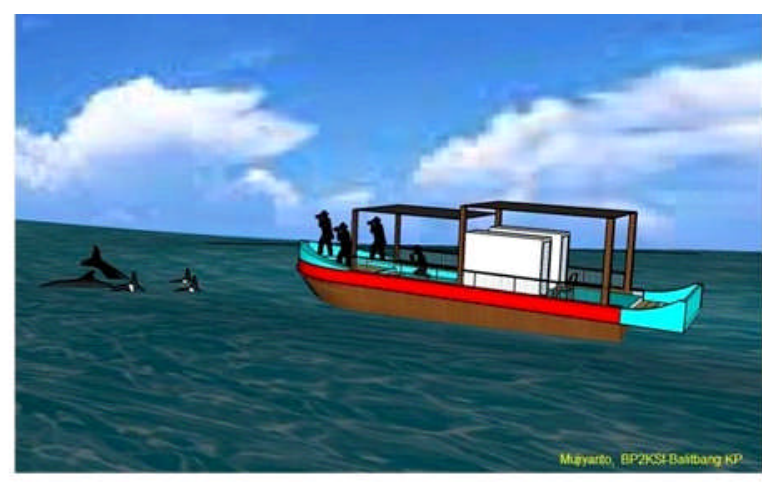

(b)

Location observation in single observer platform method.

Figure 1. (a) Track observation of cetacean and monitoring of oceanography parameters and (b) Location observation in single observer platform method at the Savu Sea National Marine Park, East Nusa Tenggara.

Table 1. Oceanographic parameters, research methods and research tools

\begin{tabular}{lcl}
\hline \multicolumn{1}{c}{ Parameter } & Unit & Tools \\
\hline Sea Surface Temperature (SST) & ${ }^{\circ} \mathrm{C}$ & In situ, Water Quality Checker \\
Dissolved Oxygen (DO) & $\mathrm{mg} / \mathrm{l}$ & In situ, Water Quality Checker \\
$\mathrm{pH}$ & $\mathrm{unit}$ & In situ, Water Quality Checker \\
Total Dissolved Solid (TDS) & $\mathrm{mg} / \mathrm{l}$ & In situ, Water Quality Checker \\
Salinity & $\% 00$ & In situ, Water Quality Checker \\
\hline
\end{tabular}




\section{RESULTS AND DISCUSSION Results}

\section{The Composition of the Dolphin Species}

Observation of dolphin appearances done in November and March-April period in waters within and outside the Savu Sea National Marine Park (KupangRote Ndao Island, East Sumba, Central Sumba, West Sumba, Southwest Sumba and Manggarai) found 7 species and 1 group which cannot be identified during the study and then categorized as un-dolphin (Table 2 , no. 8). The difference between the two observation periods of 3 species of dolphins were not found in November period, specifically Risso's dolphin, Rough- toothed dolphin and Stripped dolphin. In regards with the data generated during observations, the highest appearance ( \pm 401 individuals in November 2015 and \pm 518 individuals in March-April 2016) of dolphin composition was the Spinner dolphin species. This dolphin in both periods was fairly dominant (both in November and March-April). Each species was found during observation species bottlenose dolphin (Tursiops truncates), fraser's dolphin (Lagenodelphis hosei), pentropical spotted dolphin (Stenella attennuata), risso's dolphin (Grampus griseus), rough-toothed dolphin (Steno bredanensis), spinner dolphin (Stenella longirostris) and stripped dolphin (Stenella coeruleoalba).

Similarity of Dolphin Species

Table. 2. The sighting of dolphin in November 2015 and March-April 2016

\begin{tabular}{lllcc}
\hline \multirow{2}{*}{ No. } & \multicolumn{1}{c}{ Common name } & \multicolumn{1}{c}{ Scientific name } & \multicolumn{2}{c}{ Appearance } \\
\cline { 3 - 5 } & & & November & March-April \\
\hline 1. & Bottlenose dolphin & Tursiops truncatus & + & + \\
2. & Frazer's dolphin & Lagenodelphis hosei & + & + \\
3. & Pantropical spotted dolphin & Stenella attennuata & + & + \\
4. & Risso's dolphin & Grampus griseus & - & + \\
5. & Rough-toothed dolphin & Steno bredanensis & - & + \\
6. & Spinner dolphin & Stenella longirostris & + & + \\
7. & Stripped dolphin & Stenella coeruleoalba & - & + \\
8. & Un-dolphin & & + & + \\
\hline
\end{tabular}

Appearance: $(+)=$ appeared; $(-)=$ not visible

The analysis result of the dolphin species similarity between the territorial waters was generated in November 2015. The location with the level of similarity was divided into 3 groups of territorial waters. The first one is between the Rote Ndao and West Sumba region, the second group is between Central Sumba and Southwest Sumba region, and the third group is between East Sumba and Manggarai. The species appearance in the Rote Ndao and Sumba Barat regions also has similarities in term of species dolphins species in Kupang (Fig. 2).

The level of similarity of dolphin species in observation period of March-April formed 1 group that nearly at the same level with second group. The first group is the region of East Sumba and Central Sumba, from the first group was found similar species (spinner dolphin) results in the region of Southwest Sumba. The three areas of the waters (East Sumba, Central Sumba and Southwest Sumba) form the next group with Kupang region (Fig. 2). The results of the dolphin similarity analysis in both observations show that the species observed in Sabu Raijua has different species compared with the existing species in the Savu Sea National Marine Park area. Its species has different sighting in Sabu Raijua is Bottlenose dolphin. In November 2015, the type of dolphin found in Sabu Raijua, shows different forms of dendrogram from other regions, whereas in March-April 2016, the presence of the type of dolphin in Sabu Raijua also showed a weak similarity with the waters area, visible similarities of the type of dolphin - the closest dolphin to the Rote Ndao area.

\section{The Correlation Between Dolphin Appearance and Oceanographic Parameters}

The analysis result of dolphin occurrence based on oceanographic parameters (water temperature, $\mathrm{pH}$, DO, TDS and salinity) was generated from both observations (November 2015 and March 2016 period) shown with angles formed from PCA dendrograms. The appearance of dolphins in November from the oceanographic parameters that resulted is the parameters of SST, TDS and salinity, but at the angles created by TDS and salinity parameters show the opposite distance between the two parameters. The 
angle d" $45^{\circ}$ illustrates the closeness relationship between dolphin occurrence and water surface temperature parameters (Fig. 3). The result of correlation analysis seen dolphin appearance with angle d" $45^{\circ}$ is water surface temperature parameter, besides $\mathrm{pH}$ and salinity. The second result of dolphin appearance observation shows that the water surface temperature becomes the main parameter that be found determine difference of dolphin appearance in waters of Savu Sea.

Distribution of dolphin appearances with the results

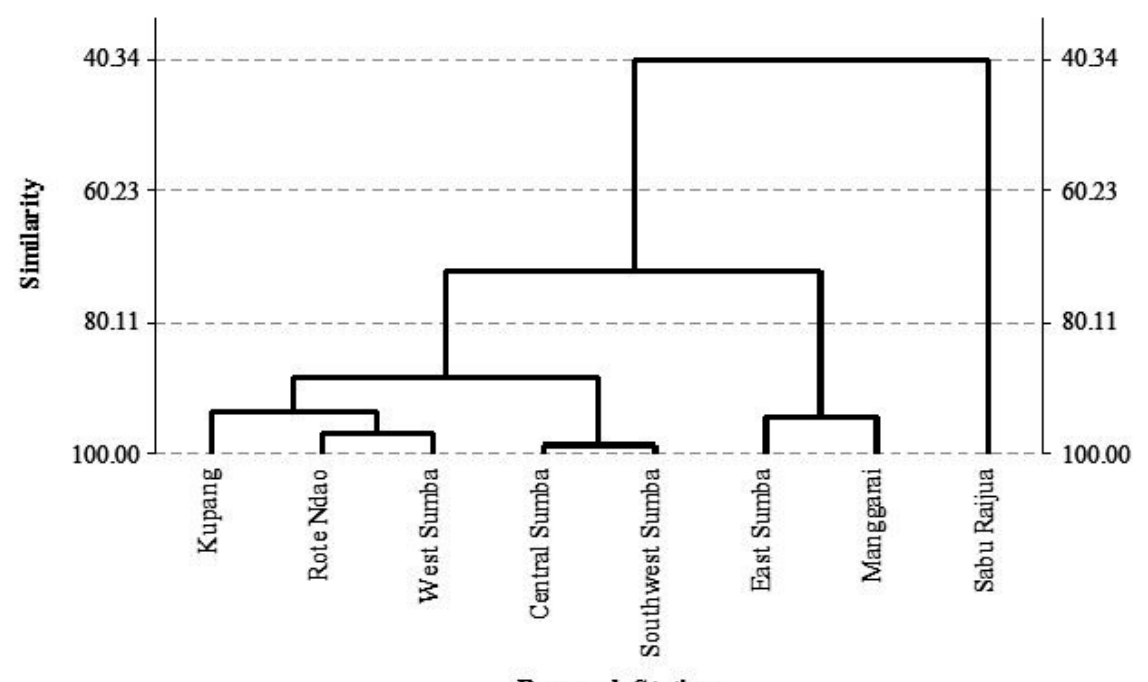

Research Stations

November 2015

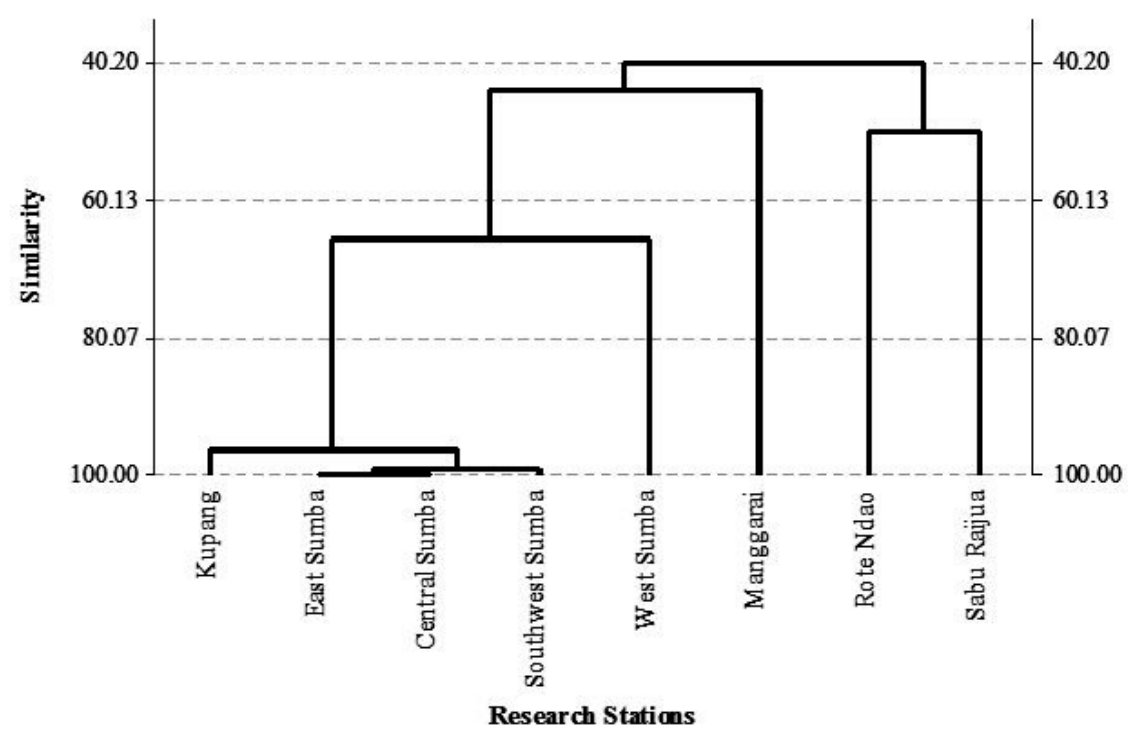

March-April 2016

Figure 2. The group of dolphin sighting in waters around Savu Sea National Marine Park, East Nusa Tenggara. 


\section{Biplot (axes F1 and F2: 81.99\%)}

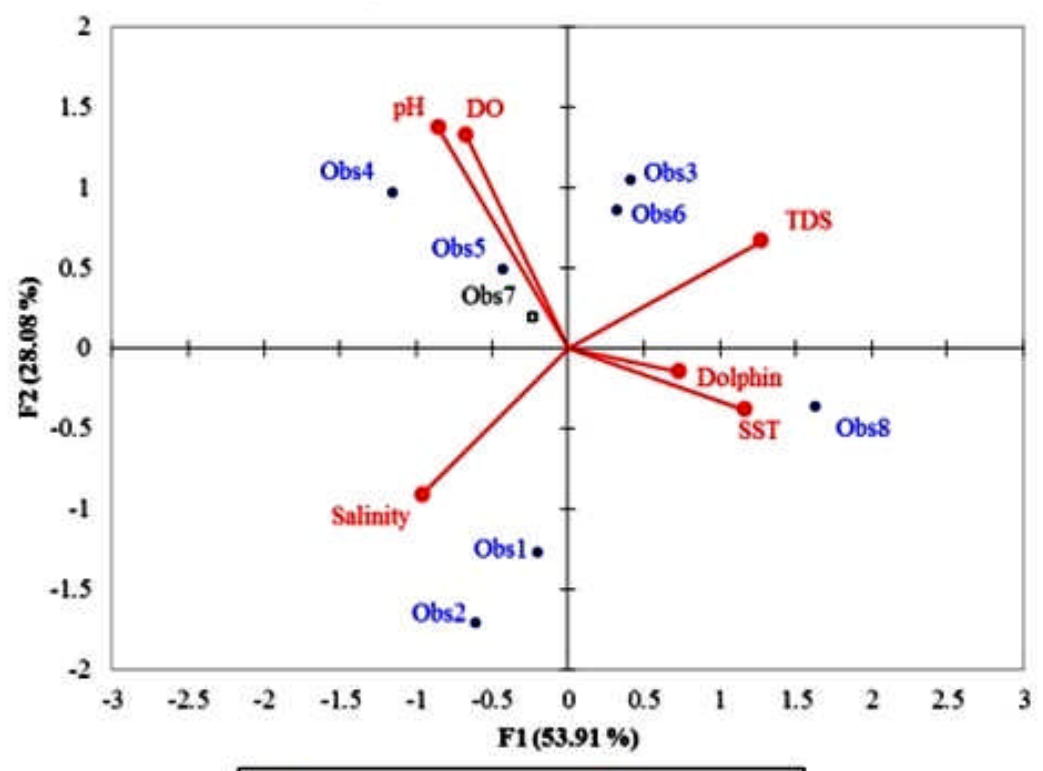

- Active oSupplementary $\bullet$ Active variables

\section{November 2015}

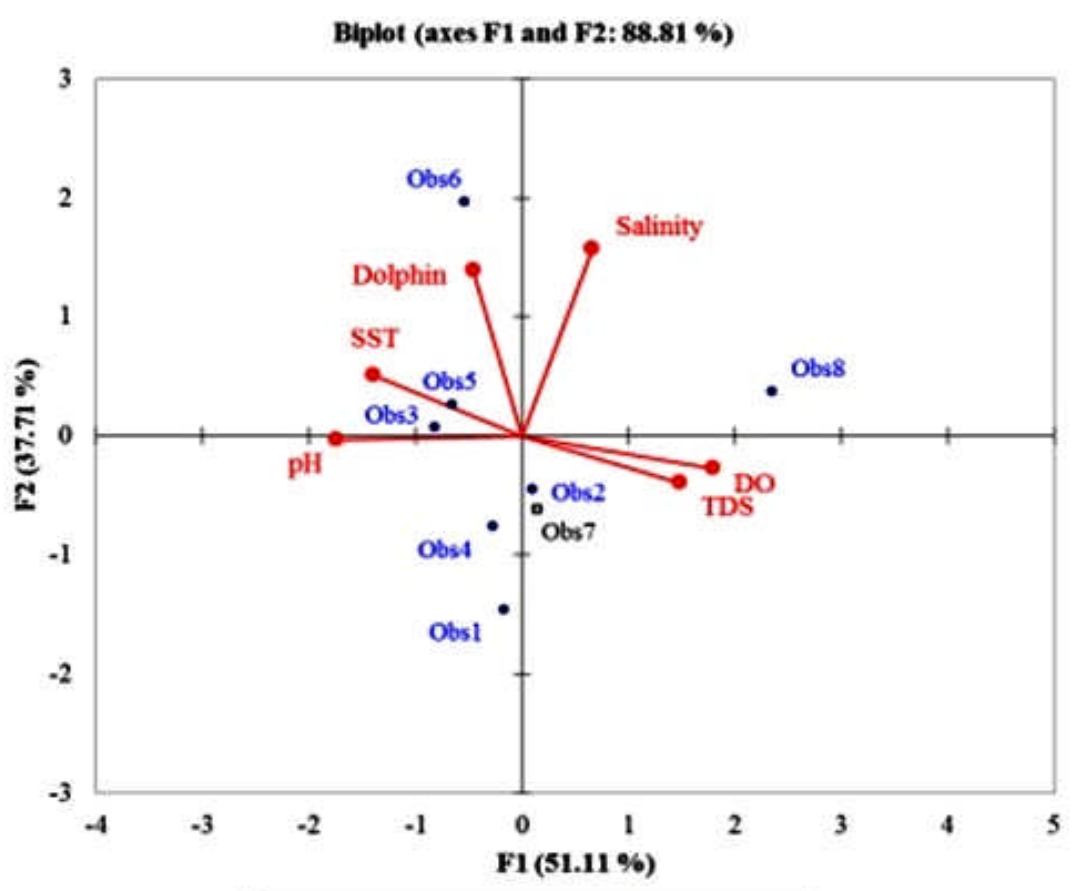

- Active D Supplementary Active variables

\section{Maret-April 2016}

Figure 3. The correlation of dolphin appearance with oceanographic parameters in Savu Sea National Marine Park, East Nusa Tenggara. 
of closeness relationship with oceanographic parameters, produced the most influential parameter. The parameter that be found describe the real difference in this case is the surface water temperature. The presence of bottlenose dolphin shows the differences in the appearance of this species between November and March-April, where in November there

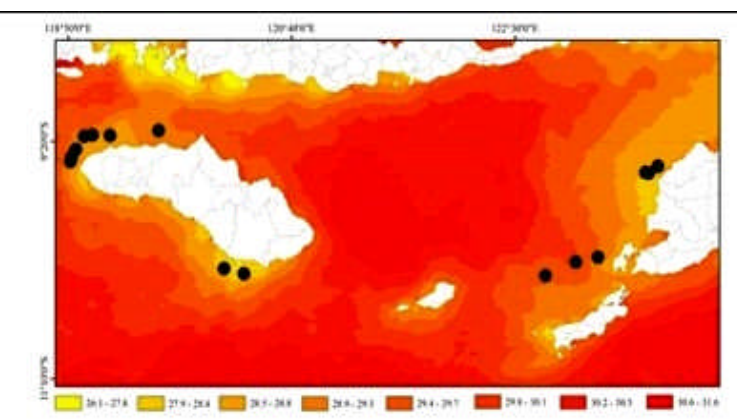

Bottlenose dolphin (November 2015) was a tendency to gather in West Sumba and Southwest Sumba regions. Then during March-April period, the dolphins at the same location were not found. The temperature values related to the presence of bottlenose dolphin ranges around 27.9$29.7^{\circ} \mathrm{C}$ (Fig. 4).

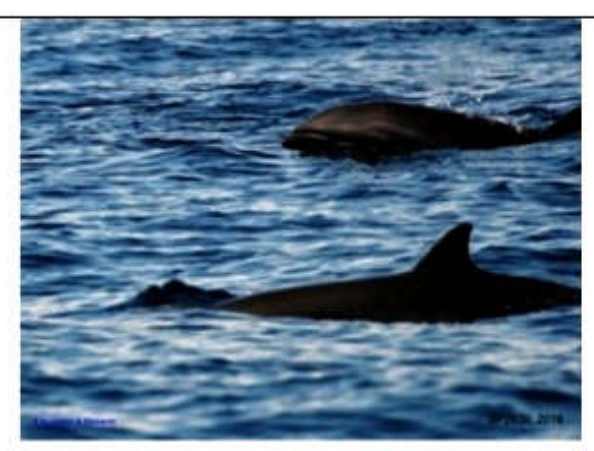

\section{Bottlenose dolphin}

Figure 4. The appearance distribution of bottlenose dolphin in the period of November and March-April in the Savu Sea.

The presence distribution of frazer's dolphin species in the Savu Sea National Marine Park Area is relatively low in observations during November and March-April period. This species only appeared around Daratan Timor, whereas in the March-April period observation, it was also occurring around the island of East Sumba. The temperature of the two observation periods when the frazer's dolphins were found at Savu Sea National Marine Park Area was between 30.8$31.5^{\circ} \mathrm{C}$ (Fig. 5). 
Composition and Distribution of Dolphin in Savu Sea National Marine Park, East Nusa Tenggara (Mujiyanto., et al)

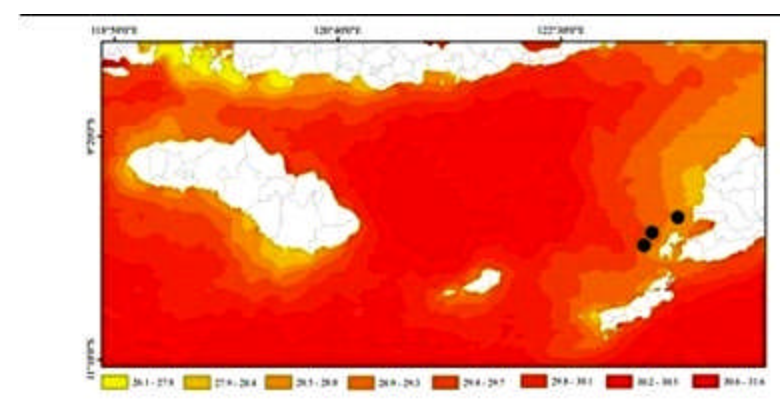

Frazer's dolphin (November 2015)

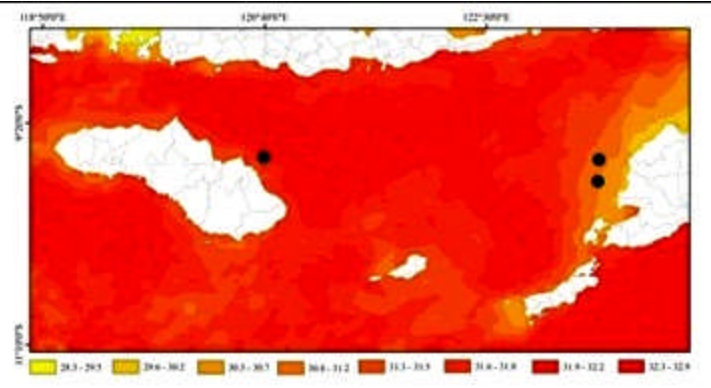

Frazer's dolphin (March-April 2016)

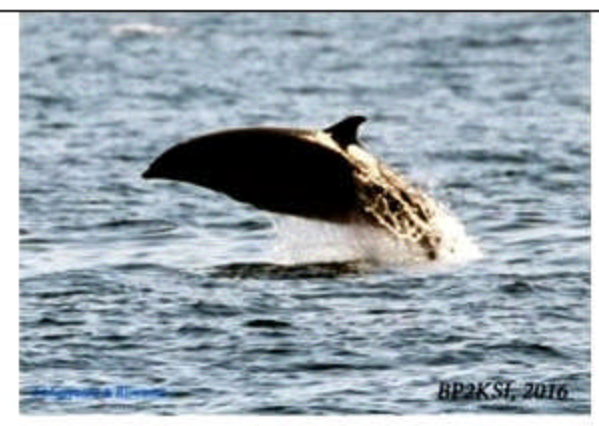

\section{Frazer's dolphin}

Figure 5. Distribution of fraser's dolphin appearance in November and March-April in Savu Sea.
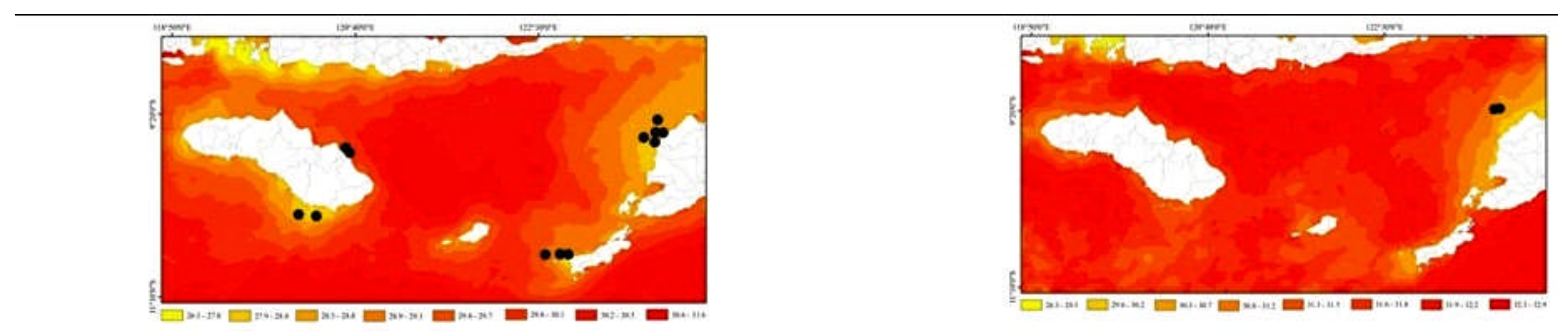

Pantropical spotted dolphin (November 2015)

Pantropical spotted dolphin (March-April 2016)

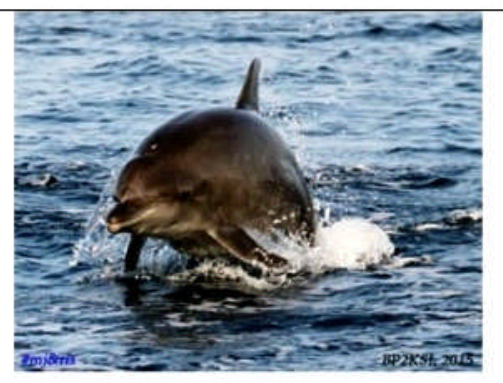

Pantropical spotted dolphin

Figure 6. The appearance distribution of pantropical spotted dolphin in the period of November and MarchApril in Savu Sea. 
The appearance of pantropical spotted dolphin during observation was found at a relatively low temperature. The temperature as in its appearance ranged around $26.1-28.8^{\circ} \mathrm{C}$ (Fig. 6). The dolphin appearance distribution was found in November in the waters of around the DaratanTimor at Central South Timor Region and of Rote Ndao area. The dolphin was also found in the vicinity of Sumba Island around Waingapu and Salura Island which are administratively included in East Sumba District.

The spinner dolphin is the highest species appeared $( \pm 401$ individuals in November 2015 and \pm 518 individuals in March-April 2016) in all waters of the Savu Sea National Marine Park Area. This high level of appearance distribution is due to the fact that this species has a very wide distribution area, covering all tropical and sub-tropical waters in the Atlantic, Pacific and Indian Oceans (Klinowska, 1991; Faizah et al., 2006). Spinner dolphin spotted more spots in November in the Central South Timor District, were Kupang District, and Rote Ndao District. This species appearance is found in November in around the Sumba
Islands including the waters of East Sumba, West Sumba, Southwest Sumba, and Central Sumba. The water temperature of spinner dolphin appearance based on the analysis results is in the range around 29.6-32. ${ }^{\circ} \mathrm{C}$ (Fig.7).

The appearance of risso's dolphin, rough-toothed dolphin and stripped dolphin during observation in the Savu Sea National Marine Park Area was noted only in March-April with locations around the Timor Mainland and Flores Mainland (Fig. 8). The highest appearance composition during the March-April observation period was stripped dolphin around District and Central South Timor District.

Some unidentified dolphins were noted due to distance and unclear observations which grouped in Un-dolphin. Their distribution was discovered in November around Kupang, East Sumba and Central Sumba districts. Its appearance in March-April period was also found around Kupang, East Sumba and Southwest Sumba districts. The surface temperature is preferably in the range of $30.5-32.5^{\circ} \mathrm{C}$ (Fig. 9).

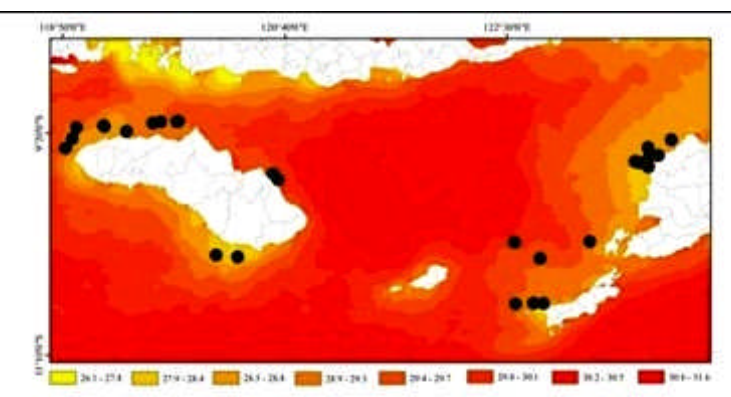

Spinner dolphin (November 2015)

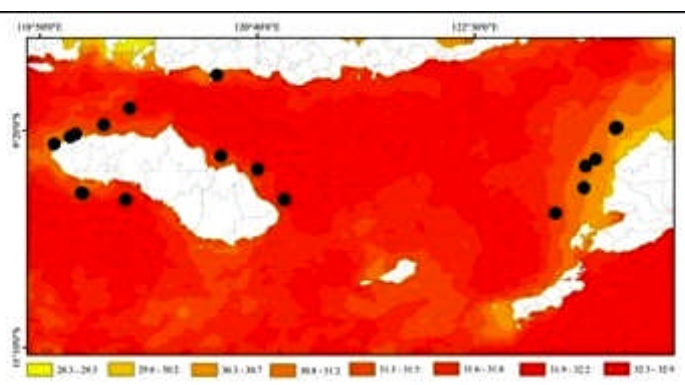

Spinner dolphin (March-April 2016)

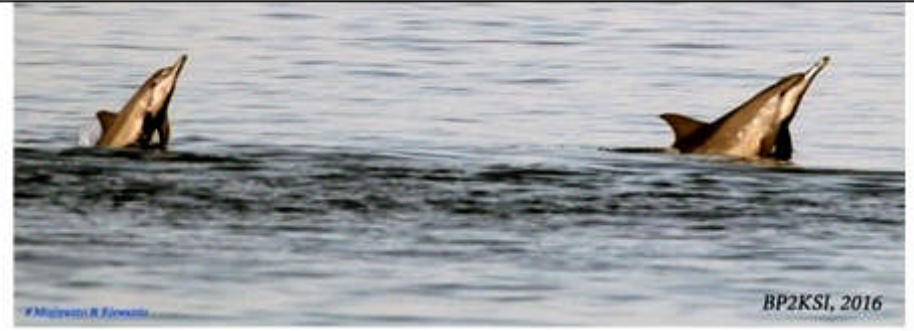

Spinner dolphin

Figure 7. Distribution of spinner dolphin appearance in the period of November and March-April in Savu Sea. 


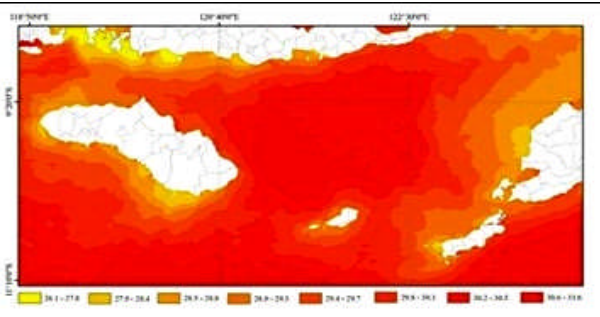

Risso's dolphin (November 2015) - not visible

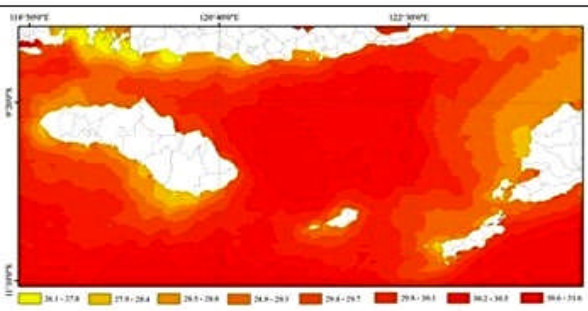

Rough-toothed dolphin (November 2015) - not visible

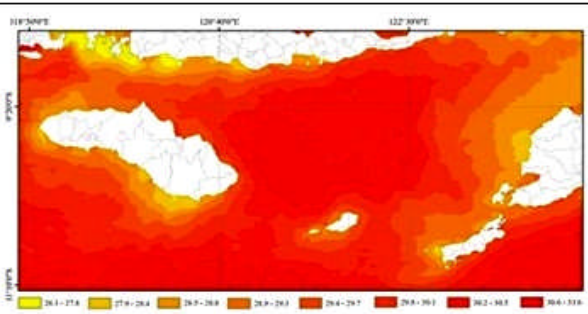

Stripped dolphin (November 2015) - not visible

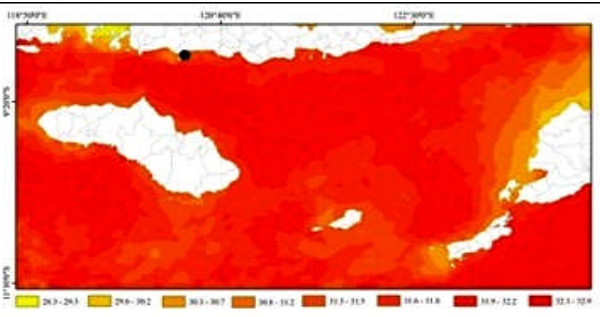

Risso's dolphin (March-April 2016)

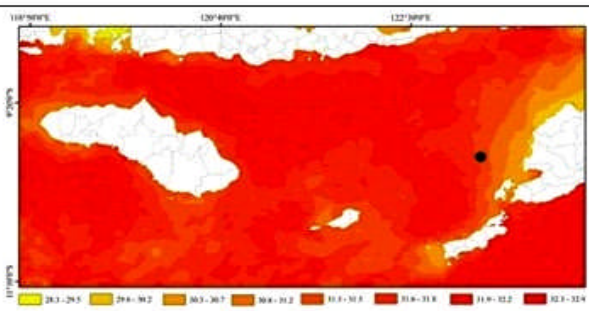

Rough-toothed dolphin (March-April 2016)

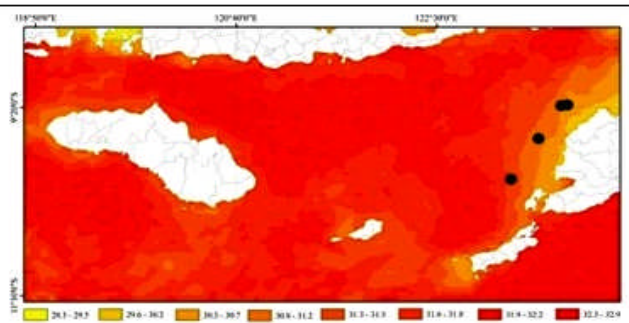

Stripped dolphin (March-April 2016)

Figure 8. The distribution of dolphin based on sea surface temperature in Savu Sea.

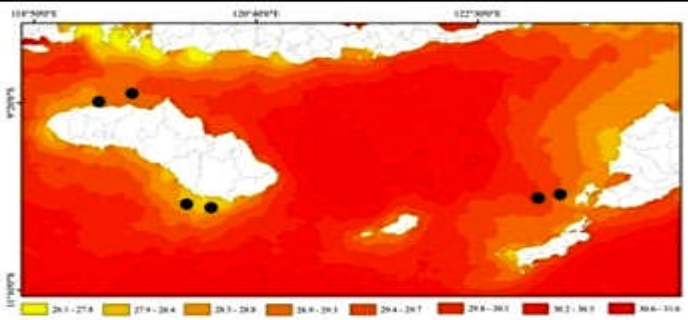

Un-dolphin (November 2015)

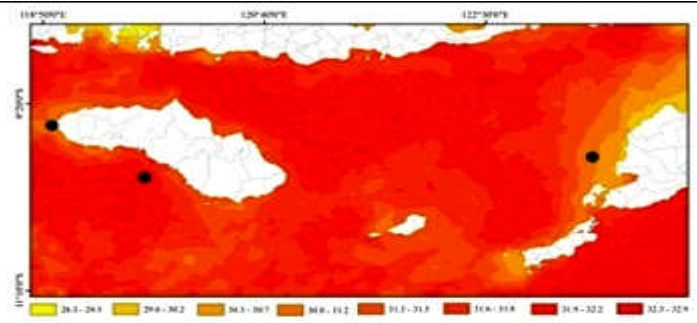

Un-dolphin (March-April 2016)

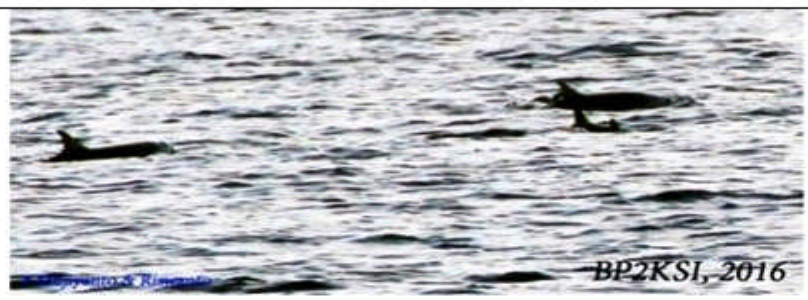

Un-dolphin

Figure 9. Distribution of un-dolphin appearance in November and March-April in Savu Sea. 


\section{Discussion \\ The Composition of Dolphins Species}

Long-dolphin (spinner dolphin) is the highest dolphin species composition during the observation in November and March-April period, followed by bottlenose dolphin and pentropical spotted dolphin. Kahn's research results (2014) reported the domination of spinner dolphin (Stenella longirostris) approximately $35.9 \%$, spotted dolphin (Stenella attenuate) around $18 \%$, and blue whale species (Balaenoptera musculus) by $12.8 \%$. Behavior and movement patterns of the Spinner dolphin are the most prominent and easily identifiable behavior species.

According to Rudolph et al. (1997), spatial distribution of spinner dolphin reaches Timor Sea, Lembata, Java Sea, Malacca Strait, Seram Sea, Flores Sea, Banda Sea, Sunda Strait, Sulawesi Sea, Papua's northern coast, Alor Island, Sumba Strait and Waters around Komodo National Park. Shane et al. (1986) and Hansen (1990) stated that in coastal waters of Gulf Mexico the composition and group size of the bottlenose dolphin always changes in a day. Carwardine (1995) stated the type of spinner dolphin has 3 (three) color patterns that are light gray on the side and white (gray white) on the abdomen. This species is often encountered in a large group of 5200 individuals even up to 1,000 individuals (Kiefner, 2002).

The dolphin compositions with high appearance during the study were bottlenose dolphin (148 dolphins in November and 72 dolphins in March-April). The observations done by Sujatmiko et al., (2015) at Kiluan Lampung Bay for 3 days with a total time of 4 hours 43 minutes indicated two species of dolphins. The species identified with highest appearance are bottlenose dolphin (Tursiops truncatus) and spinner dolphin (Stenella longirostris). Research conducted by Siahainenia \& Isnaniah (2013) shows that the dolphins identified in the waters of Kilaun Bay were Tursiops truncatus and Stenella longirostris. Bottlenose dolphin (Tursiops truncatus) is one of the species with high appearance in November and March-April period. This is due to the behavioral patterns of the bottlenose dolphin that tends to live in a group with small numbers, approximately 2-15 individuals (Shane et al., 1986) and associated with other species of cetaceans (Jefferson et al., 1993). The distribution of bottlenose dolphin (Tursiops truncantus) is mostly within $500 \mathrm{~m}$ from the beach, and sometimes this species lives in offshore near steep cliffs where preys may be more abundant (Priyono, 2013). Bottlenose dolphin (Tursiops truncantus) forms larger groups because of part of the strategy to prey on their dietary source of schooling fish in open water. Their diet includes fish (various sizes) and cephalopoda (squid and octopus) (Reeves et al., 2006).

\section{The Similarity of Dolphin Species}

The highest similarity of dolphin in November was found in the waters of Central Sumba and Southwest Sumba, followed by the waters of Rote Ndao and West Sumba. The highest appearance of dolphin in the two periods with higher diverse species is noted in the waters around Sumba. Meanwhile the observation of March-April period has been related to areas similarity with the appearance of highest dolphin in East Sumba, Central Sumba, and Southwest Sumba. The results of both periods indicate that the area around East Sumba dolphin appears almost continuously. It assumes that similarities in the region are related to the availability of prey and warm waters temperatures around the area. The results of Rice's study in 1967 (Salim, 2011) suggest that biota compositions included in Odontoceti feed on variations of nekton, benthic fish and cephalopods. Dolphins and porpoise are mostly fish consumers, although they also eat squid. Dolphins prey on a variety of fish with their teeth and swallow them whole, while the small dolphins feed fish and squid as the main prey that are in the epipelagic zone of open sea waters. Some of dolphin foods are seabed fish and another fish that live nearly the seabed in shallow waters close to shore, bay, and river (Weber \& Thurman, 1991).

On his study in the Sawu Sea of East Nusa Tenggara, Salim (2011) reported some Odontoceti create connections in large groups and concentrated when herding pelagic schooling fish. The dolphin species mostly move in densely packed group over large areas, this species is likely to conduct visual and acoustic communication and using broad-band echolocation clicks to search for schooling fish. If there is a group schooling fish, the dolphin group will disperse and some of them will dive beneath the group of schooling fish as their prey and lead it to the surface by swimming in a dense formation below and around the schooling fish (Evans, 1987; Salim, 2011).

The temperature difference strongly affects the existence of schooling fish. According to Laevastu \& Hela (1970), the influence of water temperature on fish behavior is most clearly seen during spawning, water temperature can accelerate or slow the beginning period of spawning in some species of fish. The extreme temperatures in the spawning ground during the spawning season can strengthen the fish to move and spawn in the other areas. 
The Relationship Between the Appearance of Dolphins and Oceanographic Parameters

Variations in distribution of several water measured quality parameters in Savu Sea waters show low fluctuations. The distribution of $\mathrm{pH}$, salinity and $\mathrm{DO}$ is relatively lower when compared to temperature and TDS content which indicated by standard deviation value $<0.3$. The condition of Savu Sea waters is greatly influenced by the mass of Indonesian Through Flow (ITF) from the Pacific Ocean to the Indian Ocean through these waters, so that the existence of complex ecosystems, dynamic pattern of inter-island stream and activities in the archipelago region have influence on temperature, nutrients, dissolved oxygen, and $\mathrm{pH}$ with the pattern of $\mathrm{pH}$ distribution (Yusron, 2012). The results from Cribb et al. (2008) on the comparison of dolphin appearance by comparing the location of no dolphin appearance in South Australia, generates that in waters with the DO range of 7.01-8.76 m/L the dolphin appearance frequency is higher than while the DO content in the range of $8.76-20.1 \mathrm{mg} / \mathrm{L}$. They almost did not find the appearance of dolphins in the last $\mathrm{DO}$ range.

Water surface temperature is a very important factor in the physiology process for all organisms, both in fish and marine mammals. Water surface temperatures also play a role in the distribution of biota in the waters. Based on the horizontal distribution of seawater temperature on the surface, the highest dolphin distribution is found during the November and March-April studies period of Savu Sea. This water area is dominated by the temperature ranging between 29.6 and $32.2^{\circ} \mathrm{C}$. High appearances during research are mostly in the morning and evening. The appearance is allegedly related to the habit of dolphin-feeding in the morning. However, they may go to a place to rest in the afternoon (Yusron, 2012). According to Carwardine (1995), the dolphins can live in warm waters and the temperature of sea water can affect the body temperature in the activity such as catch the prey.

The results from Anonimus (2009) reported that the dolphins are found at the northern part of Misool Island with a range of sea-level temperatures between 29-30 ${ }^{\circ} \mathrm{C}$, sea surface temperature conditions in 2008 rising in places where dolphins were discovered. A large group of 200 dolphins found in the Sagewin Strait with sea surface temperature of $30.3^{\circ} \mathrm{C}$, quite high compared to all dolphin meetings in 2007. Meanwhile the study results in the 2009 have shown the dolphin reappeared in the Sagewin Strait with the number of 8-15 dolphins. The appearance data show much less than the appearance of the previous year. The further study explains that a group of 30 dolphins was found in open waters between Kofiau Island and Sagewin Strait with sea surface temperature of $29.7^{\circ} \mathrm{C}$. Two groups of dolphins were also found on the north side of Salawati Island with sea surface temperature of $30.3^{\circ} \mathrm{C}$ and $29.9^{\circ} \mathrm{C}$. According to Reeves et al. (2003) in North America, bottlenose dolphins are usually found where sea-surface temperatures vary from $10-32^{\circ} \mathrm{C}$.

\section{CONCLUSION}

Dolphin composition was noted in Savu sea National Marine Park waters about seven species. Dolphin species was found during observation namely bottlenose dolphin (Tursiops truncates), fraser's dolphin (Lagenodelphis hosel), pentropical spotted dolphin (Stenella attennuata), risso's dolphin (Grampus griseus), rough-toothed dolphin (Steno bredanensis), spinner dolphin (Stenella longirostris) and stripped dolphin (Stenella coeruleoalba). The highest compotitions species are spinner dolphin, pentropical spotted dolphin, rough-toothed dolphin and frazer's dolphin. The water areas of the highest similarity dolphin species are around Sumba and Rote Ndao, while the dolphin species in Sabu Raijua was likely related to Manggarai are different from other water areas in the Savu Sea. The appearance of dolphins in the waters of the Savu Sea is closely affected with changes in sea surface temperature. The condition is related to the effect of sea surface temperature on dolphin body temperature in activity and feeding habits, so that the dolphins are active in the morning and would be going to a place to rest in the afternoon.

\section{ACKNOWLEDGMENT}

This research was conducted under the project titled "The Compliance Research of Zoning in Savu Sea National Marine Park as the Marine Protected Areas". We also would like thanks to Savu Sea National Marine Park authority or BKKPN, and also other government and non-government partners (TNC, DKP NTT Kupang, DKP TTS, DKP Sabu Raijua, DKP Sumba Timur, DKP Sumba Tengah, DKP Sumba Barat, DKP Sumba Barat Daya, Desa Nuca Mulas).

\section{REFERENCES}

Anonimus. 2009. Analisis faktor oseanografi terhadap distribusi cetacea sub ordo odonticeti di perairan Pulau Kofiau dan Misool (Oceanography factor analysis of the cetacean distribution sub ordo odonticeti in Kofiau and Misool Island Waters). Retrieved from http://media.unpad.ac.id/thesis. Accesed on $7^{\text {th }}$ May 2016. p. 71-72. 
Barnes, R. H. (1996). Sea hunters Indonesia: Fisheries and weavers of Lamalera (p. 467). New York. Oxford University Press.

Carwardine, M. (1995). Smith sonian hand books: Whales, dolphins, and porpoises (p. 256). New York. Dorling Kindersley Publishing, Inc.

Cribb, N. M. \& Seuront, L. (2008). Assessment of bottlenose dolphin (Tursiops aduncus) habitat characteristics in the estuarine waters of the Adelaide Dolphin Sanctuary, South Australia. Journal of Marine Animals and Their Ecology, 1 (1), 5-6.

Evans, P.G.H. (1987). The natural history of whales and dolphins (p. 360). Christopher Helm Publication Ltd. London. UK.

Fauziah, R., Dharmadi, \& Punomo, F. S. (2006). Distribusi dan kepadatan lumba-lumba Stenella longirostris di Laut Sawu, Nusa Tenggara Timur (The distribution and density of spinner dolphin Stenella longirostris in Savu Sea, East Nusa Tenggara). J. Lit. Perik. Ind. 12 (3), 175-181.

Hansen, L. J. (1990). California coastal bottlenose dolphins. (In: S. Leatherwood and R.R. Reeves Eds). San Diego. Academic Press. Inc. p. 403-420.

Jefferson, T. A., Leatherwood, S., \& Webber, M. A. (1993). FAO species identification guide: marine mammal soft the world ( $7^{\text {th }} \mathrm{Ed}$ ) (p. 320). Roma. Food and Agriculture Organization of the United Nations.

Jeffferson, T. A., \& Barbara, E. C. (1994). A global review of porpoise (Cetacea: Phocoenidae) mortality in gillnets. Elsevier: Biological Conservation, 67 (2), 167-183.

Kahn, B. (2003). Solor-Alor visual and acoustic cetacean survey: Interim report April-May 2003 survey period. The Nature Conservancy South East Asia Center for Marine Protected Areas. Bali. Interim report on field activities in 2003. Retrieved from http://komodonationalpark/publications/soloralorinterimreports.html. $27 \mathrm{p}$.

Kahn, B. (2014). Rapid ecological assessment (REA) for cetaceans and seabirds in the Savu Sea National Park. Intern report on field activities in 2013. APEX. 45 p.

Kiefner, R. (2002). Whales and Dolphins. Cetacean World Guide (p. 305). Germany: Unterwasserachiv.
Retrieved from http://ejournal.unri.ac.id/index.php/ JIPAS.

Klinowska, M. (1991). The IUCN red data book: Dolphins, Porpoises and Whales of the World ( $\mathrm{p}$. 429). UK. IUCN, Gland, Switzerland \& Cambridge Published.

Keputusan Menteri Negara Lingkungan Hidup RI. (2004). Surat Keputusan Menteri Negara Lingkungan Hidup Republik Indonesia. Nomor: 51 Tahun 2004 tentang Baku Mutu Air Laut untuk Biota Laut. Jakarta. Retrieved from http://ppkkp3k.kkp.go.id/ver2/media/download.

Keputusan Menteri Kelautan dan Perikanan RI. (2014). SK Men. KP RI Nomor: KEP.38/MEN/2014 tentang Pencadangan Kawasan Konservasi Perairan Nasional Laut Sawu dan Sekitarnya di Provinsi Nusa Tenggara Timur. Jakarta. Retrieved from http://kkji.kp3k.kkp.go.id/index.php/ dokumen.

Keputusan Menteri Kelautan dan Perikanan RI. (2014). SK Men. KP RI Nomor: 5/KEPMEN-KP/ 2014 tentang Kawasan Konservasi Perairan Nasional Laut Sawu dan Sekitarnya di Provinsi Nusa Tenggara Timur. Jakarta. Retrieved from http:/ /kkji.kp3k.kkp.go.id/index.php/dokumen/regulasihukum/keputusan-menteri.

Keputusan Menteri Kelautan dan Perikanan RI. (2014). SK Men. KP RI Nomor: 6/KEPMEN-KP/ 2014 tentang Rencana Pengelolaan dan Zonasi Taman Nasional Perairan Laut Sawu dan Sekitarnya di Provinsi NTT Tahun 2014-2034. Jakarta. Retrieved from http://kkji.kp3k.kkp.go.id/ index.php/dokumen.

Laevastu T, \& Hela, I. (1970). Fisheries Oceanography (p. 596). Fishering News Book, London.

Mustika, P. L. K. (2006). Marine mammals in the Savu Sea (Indonesia) indigenous knowledge, threat analysis and management option. Thesis for the degree masters of science (p. 231). James Cook University. Australia.

Pet-Soedo, L. (2002). The solor and alor islandsexpedition results (p. 153). The Solor and Alor Islands, NTT-2007 Survey Report. WWF-TNC Indonesia. Retrieved from http://dkpalor.esy.es/ upload/2007_WWF ID-Solar Survey.

Priyono, A. (2013). Lumba-lumba di Indonesia. Jurusan Sumberdaya Hutan (Dolphins in Indonesia. 
Department of Forest Resources). J. Lit. Hutan dan Konservasi Alam. 10 (3), 283-296.

Reeves, R. R., Smith, B. D., Crespo, E. A., \& Notarbartolo, S. G. (2003). Dolphins, Whales and Porpoises: 2002-2010 Conservation Action Plan for the World's Cetaceans (9th Ed.) (p. 139). Switzerland and Cambridge, UK. IUCN/SSC Cetacean Specialist Group.

Reeves, R., \& Notarbartolo, S. G. (2006). The status and distribution of cetaceans in the Black Sea and Mediterranean Sea (p. 137). Malaga, Spain. IUCN Centre for Mediterranean Cooperation.

Rudolph, P., Smennk, C., \& Leatherwood, S. (1997). Preliminary checklist of cetacean in the Indonesia Archipelago and adjacent waters. Zoologische Verhandelingen. p. 312-338.

Salim, D. (2011). Konservasi mamalia laut (cetacean) di perairan Laut Sawu, Nusa Tenggara Timur (Conservation marine mammal (cetacean) in Savu Sea, East Nusa Tenggara). Jurnal IImu Kelautan. 4(1), 18.

Setiawan, A. (2004). Sebaran dan Tingkah Laku Cetacea di Perairan Sekitar Taman Nasional Komodo, Flores, Nusa Tenggara Timur (Distribution and behaviour of cetacean in around Komodo National Marine Park Waters, Flores, East Nusa Tenggara). Skripsi. Bogor. Institut Pertanian Bogor. $61 \mathrm{p}$.
Shane, S. H., Wells, R. S., \& Würsig, B. (1986). Ecology, behaviour and social organisation of the bottlenose dolphin: a review. Marine Mammal Sci. 2 (1), 34-63.

Siahainenia, S. R., \& Isnaniah. (2013). Jenis dan distribusi lumba-lumba di perairan Teluk Kiluan Lampung (Type and distribution of dolphins in Kilauan Bay waters, Lampung). Jurnal IImu Perairan. 8 (1), 29-35.

Sujatmiko, T., \& Rahmania, N. A., (2015). Jenis dan distribusi lumba-lumba di perairan Teluk Kiluan Lampung (Type and Distribution of dolphins in Kiluan Bay waters, Lampung). Retrived from http:/ /himiteka.lk.ipb.ac.id/2015/12/31/jenis-dandistribusi-lumba-lumba. $35 \mathrm{p}$.

Weber, H. H., \& Thurman, H. V. (1991). Marine Biology (p. 424). Harper Collins Publisher. Inc. New York.

Wells, R. S., Howard, L., Rhinehart, L. J., Hansen, J. C., Sweeney, F. I., Towndens, R. S., David R. C., Michael D. S., Aleta A. H., \& Teri, K. R. (2004). Bottlenose dolphins as marine ecosystem sentinels: developing a health monitoring system. Eco. Health Journal, (1). 246-254.

Yusron, E. (2012). Biodiversitas jenis cetacean di Perairan Lamalera, Kupang, Nusa Tenggara Timur (Biodiversitas type of cetacean in Lamalera Waters, Kupang East Nusa Tenggara). Jurnal IImu Kelautan, 17 (2), 59-62. 